\title{
RADIATION EXPOSURE TO THE POPULATION OF EUROPE FOLLOWING THE CHERNOBYL ACCIDENT
}

\author{
V. Drozdovitch ${ }^{1, *}$, A. Bouville ${ }^{2}$, N. Chobanova ${ }^{3}$, V. Filistovic ${ }^{4}$, T. Ilus ${ }^{5}$, M. Kovacic ${ }^{6}$, \\ I. Malátová ${ }^{7}$, M. Moser ${ }^{8}$, T. Nedveckaite ${ }^{4}$, H. Völkle ${ }^{8,9}$ and E. Cardis ${ }^{1}$ \\ ${ }^{1}$ International Agency for Research on Cancer, 150 cours Albert-Thomas, 69372 Lyon Cedex 08, France \\ ${ }^{2}$ DHHS, NIH, National Cancer Institute, Division of Cancer Epidemiology and Genetics, EPS 7094, \\ Bethesda, MD 20892, USA \\ ${ }^{3}$ National Center of Radiobiology and Radiation Protection, 132 K. Ohridski Boulevard, \\ Sofia, Bulgaria \\ ${ }^{4}$ Institute of Physics, Savanoriu Avenue 231, Vilnius, Lt-2053, Lithuania \\ ${ }^{5}$ STUK Radiation and Nuclear Safety Authority, P.O. Box 14, FIN-00881 Helsinki, Finland \\ ${ }^{6}$ General Hospital 'Sveti Duh', ENT and Head and Neck Surgery Department, Ul. Sv. Duha 64, \\ 10000 Zagreb, Croatia \\ ${ }^{7}$ National Radiation Protection Institute, Šrobárova 48, 10000 Praha 10, Czech Republic \\ ${ }^{8}$ Swiss Federal Office of Public Health, Radiation Protection, 3003 Bern, Switzerland \\ ${ }^{9}$ University of Fribourg, 3 Chemin du Musée, 1700 Fribourg, Switzerland
}

\section{Received August 30 2006, amended November 22 2006, accepted November 252006}

On the occasion of the 20th anniversary of the Chernobyl accident an attempt has been made to evaluate the impact of the Chernobyl accident on the global burden of human cancer in Europe. This required the estimation of radiation doses in each of the 40 European countries. Dose estimation was based on the analysis and compilation of data either published in the scientific literature or provided by local experts. Considerable variability has been observed in exposure levels among the European populations. The average individual doses to the thyroid from the intake of ${ }^{131} \mathrm{I}$ for children aged $1 \mathrm{y}$ were found to vary from $\sim 0.01 \mathrm{mGy}$ in Portugal up to $750 \mathrm{mGy}$ in Gomel Oblast (Belarus). Thyroid doses to adults were consistently lower than the doses received by young children. The average individual effective doses from external exposure and ingestion of long-lived radiocaesium accrued in the period 1986-2005 varied from $\sim 0$ in Portugal to $\sim 10 \mathrm{mSv}$ in Gomel Oblast (Belarus) and Bryansk Oblast (Russia). The uncertainties in the dose estimates were subjectively estimated on the basis of the availability and reliability of the radiation data that were used for dose reconstruction in each country.

\section{INTRODUCTION}

On 26 April 1986 an accident occurred at the Chernobyl power plant located in north-western Ukraine close to the border with Belarus. Following this, the most severe nuclear accident to date, large amounts of radioactive materials were released into the atmosphere from the destroyed nuclear reactor, including $(1.2-1.8) \times 10^{18} \quad \mathrm{~Bq}$ of ${ }^{131} \mathrm{I}$, and $\sim 1.4 \times 10^{17} \mathrm{~Bq}$ of long-lived ${ }^{134} \mathrm{Cs}$ and ${ }^{137} \mathrm{Cs}^{(1)}$. Atmospheric transport of these and other radionuclides caused serious contamination in Belarus and in Ukraine, as well as in the western part of the Russian Federation close to the Chernobyl power plant. The radioactive debris from the power plant was also widely dispersed over much of the territory of Europe ${ }^{(2)}$. On the occasion of the 20th anniversary of the accident, an attempt has been made to evaluate possible impact of the accident on the burden of human cancer among the European population ${ }^{(3)}$. One of the main aspects of this evaluation was the prediction of the number of cancer cases that might

${ }^{*}$ Corresponding author: drozdovitch@iarc.fr be attributed to the Chernobyl accident up to now and in the future. This required the estimation of radiation doses for each country in Europe.

The doses received during the first year after the accident were evaluated in most European countries shortly after the accident; the results are summarised in reports published in 1987 by $\mathrm{NEA}^{(4)}$ (for member countries of the Organisation for Economic Cooperation and Development) and in 1988 by UNSCEAR $^{(5)}$ (for all of Europe). Since that time, however, numerous measurements of radiation in the environment, in foodstuffs and in humans have been carried out, including a comprehensive monitoring programme developed to prepare an Atlas of ${ }^{137} \mathrm{Cs}$ deposition in Europe after the Chernobyl acci$\operatorname{dent}^{(2)}$. In addition, metabolic models describing the biokinetics of radionuclides in man have improved since 1987-1988 and revised dose coefficients for inhalation $^{(6)}$ and ingestion ${ }^{(7)}$ as well as conversion factors for external exposure ${ }^{(8)}$ have become available. Political changes have also occurred towards the end of the past century, leading to the creation of new independent states in Europe and to the release of additional information on radiological 


\section{DROZDOVITCH ET AL.}

measurement data, notably in Belarus, Russia and Ukraine. For all these reasons, there was a need to update the estimates of exposure summarised in the UNSCEAR 1988 Report $^{(5)}$.

This paper focuses on 40 European countries: Albania, Austria, Belarus, Belgium, Bosnia and Herzegovina, Bulgaria, Croatia, Cyprus, the Czech Republic, Denmark, Estonia, Finland, France, Germany, Greece, Hungary, Iceland, Ireland, Italy, Latvia, Liechtenstein, Lithuania, Luxembourg, Macedonia, Malta, Moldova, the Netherlands, Norway, Poland, Portugal, Romania, the Russian Federation, Serbia and Montenegro, Slovakia, Slovenia, Spain, Sweden, Switzerland, Ukraine and the United Kingdom. These countries constitute the whole of what is defined geographically as Europe, excluding, however, the Caucasus, Turkey, Andorra and San Marino. In the Russian Federation, only the four most contaminated Oblasts (Bryansk, Kaluga, Orel and Tula, which represent only a small fraction of the territory of that country) are included. The following doses were re-evaluated:

(1) age-dependent thyroid doses from the intake of ${ }^{131}$ I via inhalation and ingestion within 2 months after the accident;

(2) whole-body doses for adults from the intake of ${ }^{134} \mathrm{Cs}$ and ${ }^{137} \mathrm{Cs}$ for the period from 1986 to 2005 as well as projected doses up to 2065; and

(3) whole-body doses for adults due to external irradiation from radionuclides deposited on the ground for the period from 1986 to 2005 as well as projected doses up to 2065 .

\section{METHODS}

To obtain the best possible dose estimates, attempts were made to contact experts in all European countries (except Bosnia and Herzegovina, Liechtenstein and Luxembourg). For different reasons, only a limited number of local experts agreed to participate in the study. The methods of dose estimation were tailored to the types of radiation data available in each particular country. Local experts provided dose estimates for Belarus, Ukraine and the Russian Federation, where extensive work has been undertaken developing and validating methods for dose reconstruction ${ }^{(9-23)}$. For less affected European countries, information on country-specific radiation data and dose estimates was either obtained from local experts: Bulgaria, the Czech Republic, Finland, Lithuania and Switzerland; and/or from published data: Austria ${ }^{(24-28)}$, Belgium ${ }^{(29)}$, Bulgaria ${ }^{(30)}$, Croatia $^{(31,32)}$, the Czech Republic ${ }^{(33,34)}$, Estonia ${ }^{(35)}$, Finland $^{(36)}$, France ${ }^{(37)}$ Greece ${ }^{(38,39)}$, Hungary ${ }^{(40)}$, Italy ${ }^{(41,42)}$, Lithuania ${ }^{(43,44)}$, Norway ${ }^{(45,46)}$, Serbia' and Montenegro ${ }^{(47)}$, Slovakia ${ }^{(48,49)}$, Sweden ${ }^{(50)}$, Switzerland $^{(51)}$ and the United Kingdom ${ }^{(52,53)}$.
Data on ${ }^{137} \mathrm{Cs}$ deposition density and timeintegrated activity of ${ }^{131} \mathrm{I}$ and ${ }^{137} \mathrm{Cs}$ in foodstuffs during the first year after the accident were taken from the Atlas on ${ }^{137} \mathrm{Cs}$ deposition in Europe ${ }^{(2)}$ and from the 1988 UNSCEAR Report ${ }^{(5)}$, respectively. This information, together with the data on population size and structure in 1986-2005 ${ }^{(54)}$, dose coefficients for inhalation $^{(6)}$ and ingestion ${ }^{(7)}$, and conversion factors for external exposure ${ }^{(8)}$, was used to estimate doses. Although a large variability of exposures due to the Chernobyl fallout has been observed within some countries in Europe (i.e. Greece, France, Switzerland, Norway, Sweden, etc.), this study focuses on the evaluation of countrywide average doses for each country. However, in Belarus, Russia and Ukraine, doses were also estimated for the most contaminated regions in these countries. For some countries (Albania, Bosnia and Herzegovina, Iceland, Macedonia, Malta, Moldova) input data were very limited or were not available at all. Therefore, interpolation between neighbouring countries was applied to derive the necessary data, wherever it was possible.

\section{Ground deposition of radionuclides}

The radioactive debris released into the atmosphere was widely dispersed over the territory of Europe, with the highest levels of ground contamination in Belarus, Ukraine and the western part of the Russian Federation. Outside these most affected regions, the contamination levels were, in general, much lower. With respect to internal exposure, the most important radionuclides were ${ }^{131} \mathrm{I}$, ${ }^{134} \mathrm{Cs}$ and ${ }^{137} \mathrm{Cs} .{ }^{134} \mathrm{Cs}$ and ${ }^{137} \mathrm{Cs}$ were the most important radionuclides for external exposure, although a number of other radionuclides, particularly ${ }^{95} \mathrm{Zr}-\mathrm{Nb},{ }^{103} \mathrm{Ru},{ }^{106} \mathrm{Ru}$, ${ }^{131} \mathrm{I},{ }^{132} \mathrm{Te}-\mathrm{I}$ and ${ }^{140} \mathrm{Ba}-\mathrm{La}$, contributed to a varying extent to the dose from external irradiation shortly after deposition on the ground.

The deposition density of ${ }^{137} \mathrm{Cs}$ on the ground is the only quantity that could be reliably measured years after the Chernobyl accident. A comprehensive monitoring programme of ${ }^{137} \mathrm{Cs}$ deposition was conducted between 1992 and 1996 in all of Europe, with the exception of Albania, Bosnia and Herzegovina, Bulgaria, Macedonia, Serbia and Montenegro and Iceland. As a result, an Atlas of ${ }^{137} \mathrm{Cs}$ deposition in Europe after the Chernobyl accident was prepared $^{(2)}$. This information, together with data on the radionuclide composition of the deposited activity that was measured shortly after the accident was the basis of the dose assessments.

Country-wide average deposition densities of ${ }^{137} \mathrm{Cs}$ from Chernobyl fallout and ratios of activities of selected radionuclides to activity of ${ }^{137} \mathrm{Cs}$ in deposition are given in Table 1 for European countries. For some countries, data on deposition of ${ }^{99} \mathrm{Mo}$, 
EXPOSURE IN EUROPE FROM CHERNOBYL

Table 1. Country/region-wide average deposition densities of ${ }^{137} \mathrm{Cs}$ from Chernobyl fallout and ratio of activity of selected radionuclides to activity of ${ }^{137} \mathrm{Cs}$ in deposition observed in European countries.

\begin{tabular}{|c|c|c|c|c|c|c|c|c|}
\hline \multirow[t]{2}{*}{ Country } & \multirow{2}{*}{$\begin{array}{c}{ }^{137} \mathrm{Cs} \text { deposition } \\
\text { density }^{(2)}\left(\mathrm{kBq} \mathrm{m}^{-2}\right)\end{array}$} & \multicolumn{7}{|c|}{ Ratio of activity to ${ }^{137} \mathrm{Cs}$ in deposition at the time of the main deposition ${ }^{(5)}$} \\
\hline & & ${ }^{95} \mathrm{Zr}$ & ${ }^{103} \mathrm{Ru}$ & ${ }^{106} \mathrm{Ru}$ & ${ }^{131} \mathrm{I}$ & ${ }^{132} \mathrm{Te}$ & ${ }^{134} \mathrm{Cs}$ & ${ }^{140} \mathrm{Ba}$ \\
\hline Albania $^{\mathrm{a}}$ & 7.2 & 0.1 & 2.5 & 0.6 & 3.8 & 7 & 0.5 & 1.5 \\
\hline Austria & $18.7^{(24)}$ & - & 1.3 & $0.46^{(24)}$ & 5 & 4.8 & $0.57^{(24)}$ & - \\
\hline Belarus, Brest Oblast ${ }^{(23)}$ & $18.2^{(55)}$ & $0.5-0.8$ & $2.2-2.8$ & $0.7-0.9$ & $19-23$ & $7.6-12$ & 0.5 & $1.5-2.1$ \\
\hline Belarus, Vitebsk Oblast ${ }^{(23)}$ & $1.1^{(55)}$ & 0.2 & 1.8 & 0.4 & 24 & 4.8 & 0.5 & 0.8 \\
\hline Belarus, Gomel Oblast ${ }^{(23)}$ & $154^{(55)}$ & $0.17-4$ & $1.6-3.7$ & $0.42-1$ & $8.3-21$ & $4.2-11$ & 0.5 & $0.76-7.6$ \\
\hline Belarus, Grodno Oblast ${ }^{(23)}$ & $8^{(55)}$ & 0.5 & 2.8 & 0.7 & 23 & 12 & 0.5 & 1.5 \\
\hline Belarus, Minsk Oblast ${ }^{(23)}$ & $5.8^{(55)}$ & 0.5 & 2.8 & 0.7 & 23 & 12 & 0.5 & 1.5 \\
\hline Belarus, Minsk-City ${ }^{(23)}$ & $6.2^{(55)}$ & 0.3 & 1.5 & 0.45 & 14 & 2.8 & 0.5 & 1 \\
\hline Belarus, Mogilev Oblast ${ }^{(23)}$ & $61^{(55)}$ & $0.17-4$ & $1.6-2.4$ & $0.3-0.9$ & $8.3-21$ & $4.2-11$ & 0.5 & $0.76-7.6$ \\
\hline Belgium & 0.3 & - & 1.7 & 0.5 & 6.2 & 4 & 0.55 & 1.6 \\
\hline Bosnia and Herzegovina & 6.4 & - & 1.4 & 0.3 & 5.9 & 7.2 & 0.4 & 0.7 \\
\hline Bulgaria $^{(56)}$ & 7 & 0.14 & 1.4 & 0.36 & 1.7 & 4 & 0.5 & 1.6 \\
\hline Croatia $^{(31)}$ & 3.7 & 0.14 & 2.6 & 1 & 3.3 & 6.1 & 0.4 & 0.7 \\
\hline Cyprus & $0.6^{(5)}$ & - & - & - & 3.3 & - & 0.55 & - \\
\hline Czech Republic ${ }^{(57)}$ & 4.7 & - & 1.9 & 0.3 & 13.8 & 5.1 & 0.5 & 1.0 \\
\hline Denmark & 0.36 & - & 1.5 & 0.5 & 4.7 & 4.3 & 0.55 & - \\
\hline Estonia $^{\mathrm{b}}$ & $2^{(19)}$ & 1.1 & 2.2 & 0.5 & 4.2 & 5.9 & 0.6 & 0.7 \\
\hline Finland $^{\mathrm{c}(58)}$ & 12.2 & 1.7 & 2.2 & 0.5 & 4.2 & 5.9 & 0.6 & 0.7 \\
\hline France & 0.7 & - & 1.4 & 0.3 & 7.3 & 4.8 & 0.55 & - \\
\hline Germany & 2.8 & - & 1.5 & 0.3 & 5.8 & 6.8 & 0.55 & - \\
\hline Greece $^{(38)}$ & $5.2^{(38)}$ & 0.1 & 2.5 & 0.6 & 3.8 & 7 & 0.5 & 1.5 \\
\hline Hungary & 1.9 & - & 2.5 & 0.6 & 6.2 & 6.7 & 0.55 & - \\
\hline Iceland & 0.3 & - & - & - & - & - & 0.55 & - \\
\hline Ireland & 3.1 & - & 1.5 & 0.4 & 3.1 & 3.4 & 0.55 & 0.8 \\
\hline Italy & 2.1 & - & 2 & 0.55 & 4 & 7.8 & 0.55 & - \\
\hline Latvia $^{\mathrm{d}}$ & 0.85 & 0.2 & 1.8 & 0.4 & 24 & 4.8 & 0.5 & 1.5 \\
\hline Liechtenstein ${ }^{\mathrm{e}}$ & $11.8^{(26)}$ & - & 1.3 & 0.46 & 5 & 4.8 & 0.57 & - \\
\hline Lithuania $^{(59)}$ & 3.7 & 0.4 & 1.5 & - & 23 & 12 & 0.55 & 0.72 \\
\hline Luxembourg & 1.2 & - & 1.7 & 0.5 & 7 & 4 & 0.55 & - \\
\hline Macedonia & $8.5^{\mathrm{f}}$ & - & 1.5 & 0.3 & 6 & 7.6 & 0.4 & - \\
\hline Malta $^{\mathrm{g}}$ & 1.9 & - & 1.8 & 0.5 & 3.8 & 8.5 & 0.55 & - \\
\hline Moldova & 10.1 & - & 2.9 & 0.7 & 5.2 & 6.4 & 0.55 & - \\
\hline Netherlands & 0.3 & - & 1.9 & 0.5 & 6.3 & 3.3 & 0.55 & - \\
\hline Norway & 4.7 & - & 2 & 0.5 & 16 & 2.6 & 0.55 & - \\
\hline Poland & 1.3 & - & 2.5 & 0.3 & 7.3 & 8.4 & 0.55 & - \\
\hline Portugal & 0.02 & - & 2 & 0.6 & 3.5 & 0.2 & 0.55 & - \\
\hline Romania & 6.5 & - & 2.9 & 0.7 & 5.2 & 6.4 & 0.55 & - \\
\hline Russia, Bryansk Oblast ${ }^{(60)}$ & $110^{(61)}$ & $0.07-0.14$ & 1.6 & 0.45 & $7.6-11$ & $6.7-10$ & 0.54 & $0.41-0.63$ \\
\hline Russia, Kaluga Oblast ${ }^{(60)}$ & $14.2^{(61)}$ & 0.07 & 1.5 & 0.42 & 7.7 & 6.3 & 0.5 & 0.48 \\
\hline Russia, Orel Oblast ${ }^{(60)}$ & $41^{(61)}$ & 0.07 & 1.6 & 0.43 & 8.1 & 7.1 & 0.5 & 0.49 \\
\hline Russia, Tula Oblast ${ }^{(60)}$ & $67^{(61)}$ & 0.07 & 1.6 & 0.46 & 7.9 & 6.5 & 0.5 & 0.5 \\
\hline Serbia and Montenegro & $9^{(47)}$ & - & 1.5 & 0.3 & 6 & 7.6 & 0.55 & - \\
\hline Slovakia & 3.6 & - & 1.8 & 0.3 & 11 & 7.3 & 0.50 & - \\
\hline Slovenia & 16.3 & - & 1.4 & 0.3 & 5.9 & 7.2 & 0.4 & - \\
\hline Spain & 0.06 & - & 1.5 & 0.3 & 3.9 & - & 0.55 & - \\
\hline Sweden & 4.6 & - & 2 & 0.78 & 15.9 & 1.1 & 0.55 & - \\
\hline Switzerland & 5.6 & - & 1.9 & 0.6 & 7 & 8.6 & 0.55 & - \\
\hline Ukraine, Chernihiv Oblast ${ }^{\mathrm{c}(11)}$ & $\sim 15^{\mathrm{h}}$ & 2 & 8 & 2 & 13 & 20 & 0.5 & 2 \\
\hline Ukraine, Kyiv Oblast ${ }^{\mathrm{c}(11)}$ & $\sim 30^{\mathrm{h}}$ & 2 & 8 & 2 & 13 & 20 & 0.5 & 2 \\
\hline Ukraine, Kyiv-City ${ }^{\mathrm{c}(11)}$ & $\sim 15^{\mathrm{h}}$ & 2 & 8 & 2 & 13 & 20 & 0.5 & 2 \\
\hline Ukraine, Rivno Oblast $^{\mathrm{c}(11)}$ & $\sim 40^{\mathrm{h}}$ & 2 & 8 & 2 & 13 & 20 & 0.5 & 2 \\
\hline Ukraine, Zhytomir Oblast ${ }^{\mathrm{c}(11)}$ & $\sim 50^{\mathrm{h}}$ & 2 & 8 & 2 & 13 & 20 & 0.5 & 2 \\
\hline Ukraine, remainder ${ }^{\mathrm{c}}(11)$ & $\sim 20^{\mathrm{h}}$ & 2 & 8 & 2 & 13 & 20 & 0.5 & 2 \\
\hline United Kingdom & 0.9 & - & 1.8 & 0.6 & 7.1 & 12.9 & 0.55 & - \\
\hline
\end{tabular}

${ }^{\text {a } I n t e r p o l a t i o n ~ b e t w e e n ~ G r e e c e ~ a n d ~ S e r b i a ~ a n d ~ M o n t e n e g r o ~}$

${ }^{\mathrm{b}}$ Ratios are assumed to be the same as in Finland

${ }^{\mathrm{c}}$ Ratios are decay corrected to 26 April 1986

${ }^{\mathrm{d}}$ Ratios are assumed to be the same as in Vitebsk Oblast in Belarus

${ }^{\mathrm{e}}$ Ratios are assumed to be the same as in Austria

${ }^{\mathrm{f}}$ Interpolation between northern Greece and Serbia and Montenegro

${ }^{\mathrm{g}}$ Assumed to be the same as in southern Italy

${ }^{\mathrm{h}}$ Derived from Ref. (14) 


\section{DROZDOVITCH ET AL.}

${ }^{136} \mathrm{Cs},{ }^{141} \mathrm{Ce},{ }^{144} \mathrm{Ce}$ and ${ }^{239} \mathrm{~Np}$ were also available and used for the reconstruction of external doses.

\section{Dose estimates provided by local experts}

As mentioned above, local experts from Belarus, Bulgaria, the Czech Republic, Finland, Lithuania, the Russian Federation, Switzerland and Ukraine provided dose estimates for their countries. These estimates are the results of extensive national dose reconstruction programmes. Dosimetry models used for dose reconstruction included empirical and semiempirical approaches that are based on the relationships between environmental contamination and measured levels of radionuclides in humans, and ecological models that describe the processes of transfer of radionuclide activities from ground deposition to the human body. Input data used for dose reconstruction in these countries included hundreds of thousands of results of measurements of ${ }^{131} \mathrm{I}$ in human thyroids performed in $1986^{(9,15,21,30,34)}$; and ${ }^{137} \mathrm{Cs}$ body burdens, as well as, ${ }^{137} \mathrm{Cs}$ in milk and other foodstuffs $(10,13,14,19,23,33,62-64)$. Majority of these measurements were carried out in the most contaminated states.

For other countries, the dose estimates were based on the input data and methods described below.

\section{Internal doses due to inhalation}

The internal organ doses for a person in age group $k$ arising from inhalation of air contaminated with ${ }^{131} \mathrm{I}$ and ${ }^{134,137}$ Cs during radioactive cloud passing were calculated as:

$$
D_{i, k}^{\mathrm{inh}}=C_{i}^{\mathrm{air}} \cdot\left[F_{\text {in }} \cdot \mathrm{RF}^{\mathrm{air}}+\left(1-F_{\text {in }}\right)\right] \cdot V_{k}^{\mathrm{air}} \cdot \mathrm{DF}_{i, k}^{\mathrm{inh}},
$$

where $D_{i, k}^{\text {inh }}$ is the internal dose arising from inhalation of radionuclide $i(\mathrm{mSv}) ; C_{i}^{\text {air }}$ is the timeintegrated concentration of radionuclide $i$ in outdoor air $\left(\mathrm{Bg} \mathrm{d} \mathrm{m}{ }^{-3}\right) ; F_{\text {in }}=0.6$ is the indoor occupancy factor $^{(18)}$, unitless; $\mathrm{RF}^{\mathrm{air}}$ is the reduction factor that associated with indoor occupancy, unitless; $V_{k}^{\text {air }}$ is the breathing rate of persons in age group $k^{(65)}\left(\mathrm{m}^{3}\right.$ $\left.\mathrm{d}^{-1}\right)$; $\mathrm{DF}_{i, k}^{\mathrm{inh}}$ is the inhalation dose coefficient for thyroid (in the case of inhalation of ${ }^{131} \mathrm{I}$ ) and for effective dose (in the case of inhalation of ${ }^{134} \mathrm{Cs}$ and $\left.{ }^{137} \mathrm{Cs}\right)$ for persons in age group $k^{(6)}\left(\mathrm{mSv} \mathrm{Bq}^{-1}\right)$.

The time-integrated concentrations of ${ }^{131} \mathrm{I}$, and ${ }^{134} \mathrm{Cs}$ and ${ }^{137} \mathrm{Cs}$ in outdoor air are given in Table 2. The values used in the dose calculation were taken from the UNSCEAR 1988 Report $^{(5)}$ or from published data, and were derived from the data bank of Radioactivity Environmental Monitoring at the CEC Joint Research Centre Ispra ${ }^{(66)}$. The reduction factor that associated with indoor occupancy was taken to be $0.5^{(69)}$.

\section{Internal doses due to ingestion}

The internal organ doses for a person in age group $k$ arising from ingestion of ${ }^{131} \mathrm{I}$ and ${ }^{134,137} \mathrm{Cs}$ in contaminated foodstuffs were calculated as:

$$
D_{i, k}^{\mathrm{ing}}=C_{i, k}^{\mathrm{diet}} \cdot \mathrm{DF}_{i, k}^{\mathrm{ing}},
$$

where $D_{i, k}^{\text {ing }}$ is the internal dose arising from ingestion of radionuclide $i(\mathrm{mSv}) ; C_{i, k}^{\text {diet }}$ is the yearly integrated activity intake of radionuclide $i$ by ingestion $(\mathrm{Bq})$; $\mathrm{DF}_{i, k}^{\text {ing }}$ is the ingestion dose coefficient for thyroid (in the case of ingestion of ${ }^{131} \mathrm{I}$ ) and for effective dose (in the case of ingestion of ${ }^{134} \mathrm{Cs}$ and ${ }^{137} \mathrm{Cs}$ ) for persons in age group $k^{(7)}\left(\mathrm{mSv} \mathrm{Bq}^{-1}\right)$.

\section{Internal doses due to ingestion in 1986}

Consumption of milk, milk products and leafy vegetables was considered for ${ }^{131} \mathrm{I}$ intake. No delay between the production and the consumption of milk was assumed for rural inhabitants, while for people living in urban areas the delay from milking to consumption was taken to be $1 \mathrm{~d}$. The agedependent dietary intake of ${ }^{131} \mathrm{I}$ that was taken from the UNSCEAR 1988 Report $^{(5)}$ and scientific publications and used in calculations is given in Table 2 .

Consumption of milk and milk products, leafy vegetables, grain products, other fruits and vegetables, and meat was considered for ingestion of radiocaesium. The UNSCEAR 1988 Report $^{(5)}$ and data available in scientific publications were used as the sources of information for radiocaesium intake. In the estimation of the time-integrated concentrations of ${ }^{137} \mathrm{Cs}$ in 1986 (from the time of the accident to the end of the year), the time-integrated concentrations of ${ }^{137} \mathrm{Cs}$ given in the UNSCEAR 1988 Report $^{(5)}$ for the first year after the accident were multiplied by 0.65. This reduction factor was derived from the results of measurements of ${ }^{137} \mathrm{Cs}$ concentration in skim milk powder taken in Austria ${ }^{(26)}$. The countryspecific initial activity ratio of ${ }^{134} \mathrm{Cs}$ to ${ }^{137} \mathrm{Cs}$ in deposition (see Table 1) was applied to estimate the intake of ${ }^{134} \mathrm{Cs}$ with diet.

\section{Internal doses due to ingestion during the following years}

The time-integrated activity dietary intake of ${ }^{137} \mathrm{Cs}$ in 1987 and 1988 were estimated from the integrated activity of dietary ${ }^{137} \mathrm{Cs}$ in 1986 using reduction factors of 0.65 and 0.25 , respectively. These reduction factors were derived from the measurements of ${ }^{137} \mathrm{Cs}$ activity concentration in skim milk powder taken in Austria $^{(26)}$. For later years, the dietary intake of ${ }^{137} \mathrm{Cs}$ was assumed to decrease exponentially with a half-time of $1.7 \mathrm{y}$ up to 1993 and with a half-time of 
EXPOSURE IN EUROPE FROM CHERNOBYL

Table 2. Country/region-wide average integrated activity of radionuclides in air and in $\operatorname{diet}^{(5)}$.

\begin{tabular}{|c|c|c|c|c|c|c|c|}
\hline \multirow[t]{3}{*}{ Country } & \multicolumn{3}{|c|}{ Integrated activity in air $\left(\mathrm{Bq} \mathrm{d} \mathrm{m}^{-3}\right)$} & \multicolumn{4}{|c|}{ Yearly integrated activity in diet $(\mathrm{Bq})$ of } \\
\hline & \multirow[b]{2}{*}{${ }^{131} \mathrm{I}$} & \multirow[b]{2}{*}{${ }^{134} \mathrm{Cs}$} & \multirow[b]{2}{*}{${ }^{137} \mathrm{Cs}$} & \multicolumn{2}{|c|}{${ }^{131}$ I for age group } & \multicolumn{2}{|c|}{${ }^{137} \mathrm{Cs}$ in year } \\
\hline & & & & $1 \mathrm{y}$ & $20 \mathrm{y}$ & 1986 & 1987 \\
\hline Albania $^{\mathrm{a}}$ & 50 & 4 & 8 & 2570 & 6330 & 2690 & 1750 \\
\hline Austria & $115^{(66)}$ & $6.4^{(66)}$ & $11.2^{(66)}$ & 2280 & 1650 & $11,700^{(27)}$ & 7600 \\
\hline Belgium & 30 & 2 & 5 & 560 & 730 & 420 & 270 \\
\hline Bosnia and Herzegovina & 72 & 3.4 & 7.4 & 5050 & 12,900 & 2200 & 1430 \\
\hline Bulgaria & $13.8^{(56)}$ & $4.4^{(56)}$ & $9^{(56)}$ & $4590^{(30)}$ & $7150^{(30)}$ & 8560 & 5560 \\
\hline Croatia & $61^{(31)}$ & $12^{(31)}$ & $28^{(31)}$ & $5890^{(32)}$ & 11,500 & $7790^{(32)}$ & 5060 \\
\hline Cyprus & 20 & 3.5 & 7 & 1260 & 2460 & 1140 & 740 \\
\hline Czech Republic & $140^{(66)}$ & $5.2^{(66)}$ & $10.5^{(66)}$ & 3160 & 3600 & $1670^{(33)}$ & 1090 \\
\hline Denmark & $6.7^{(66)}$ & $0.26^{(66)}$ & $0.53^{(66)}$ & 30 & 32 & 430 & 280 \\
\hline Estonia & $55^{(66) b}$ & $1^{(66) b}$ & $1.7^{(66) b}$ & 620 & 1380 & 1060 & 690 \\
\hline Finland & $47^{(67)}$ & $0.9^{(67)}$ & $1.5^{(67)}$ & $150^{(64)}$ & $150^{(64)}$ & $4200^{(68)}$ & $7300^{(68)}$ \\
\hline France & 7.9 & 0.52 & 1.2 & 590 & 610 & 1070 & 700 \\
\hline Germany & 42 & 3.2 & 6.1 & 580 & 590 & 1500 & 970 \\
\hline Greece & $40^{(38)}$ & $5^{(38)}$ & $10^{(38)}$ & 4930 & 4540 & $12,900^{(38)}$ & 8390 \\
\hline Hungary & 29 & 2.1 & 4.2 & 1570 & 1650 & 3980 & 2580 \\
\hline Ireland & 1.0 & 0.06 & 0.11 & 650 & 940 & 1970 & 1280 \\
\hline Italy & 35 & 2.2 & 4.2 & 2260 & 2650 & 5900 & 3840 \\
\hline Latvia & 55 & 1 & 1.7 & $1400^{\mathrm{c}}$ & $3460^{\mathrm{c}}$ & $850^{\mathrm{c}}$ & $320^{\mathrm{c}}$ \\
\hline Liechtenstein & $43^{(66)}$ & $4.4^{(66)}$ & $8^{(66)}$ & 2400 & 1710 & $7300^{d}$ & $4800^{\mathrm{d}}$ \\
\hline Lithuania & $270^{(44)}$ & 4.4 & 8.8 & $6250^{(44)}$ & $4300^{(44)}$ & $3600^{(59)}$ & $510^{(59)}$ \\
\hline Luxembourg & 30 & 2 & 5 & 670 & 870 & 1440 & 930 \\
\hline Macedonia & 57 & 2.5 & 5.9 & 2570 & 6380 & 2690 & 1750 \\
\hline Malta & 26 & 1.6 & 2.7 & 2100 & 1480 & 5050 & 3280 \\
\hline Moldova $^{\mathrm{f}}$ & 340 & 8 & 17 & 5380 & 7950 & 10,630 & 6900 \\
\hline Netherlands & $20^{(66)}$ & $0.9^{(66)}$ & $1.9^{(66)}$ & 230 & 630 & 760 & 490 \\
\hline Norway & 85 & 2.8 & 5.3 & 175 & 260 & 3940 & 2560 \\
\hline Poland & 72 & 4.1 & 8.2 & 2120 & 1750 & 4260 & 2770 \\
\hline Portugal & 0.07 & 0.01 & 0.02 & 2 & 5 & 40 & 30 \\
\hline Romania & 180 & 6.4 & 13.7 & 4660 & 4120 & 6880 & 4470 \\
\hline Serbia and Montenegro & 57 & 2.5 & 5.9 & 2550 & 6290 & 3020 & 1960 \\
\hline Slovakia & $110^{(66)}$ & $5.8^{(66)}$ & $10.7^{(66)}$ & 4720 & 4540 & 5150 & 3350 \\
\hline Slovenia & 72 & 3.4 & 7.4 & 5620 & 14,400 & 5600 & 3640 \\
\hline Spain & 0.14 & 0.015 & 0.03 & 30 & 45 & 160 & 100 \\
\hline Sweden & 26 & 0.56 & 1 & 220 & 270 & 2660 & 1730 \\
\hline Switzerland & $29^{(66)}$ & $1.9^{(66)}$ & $3.8^{(66)}$ & $950^{(51)}$ & $4500^{(51)}$ & $4190^{(61)}$ & $5150^{(61)}$ \\
\hline United Kingdom & $5.4^{(66)}$ & $0.48^{(66)}$ & $0.9^{(66)}$ & 180 & 180 & 530 & 340 \\
\hline
\end{tabular}

${ }^{\mathrm{a}}$ Interpolation between Greece and Serbia and Montenegro

${ }^{\mathrm{b}}$ Assumed to be the same as in Helsinki

${ }^{\mathrm{c}}$ Assuming the same transfer factors as in Vitebsk Oblast in Belarus

${ }^{\mathrm{d} A s s u m i n g}$ the same transfer factors as in Austria

${ }^{\mathrm{e}}$ Assumed to be the same as in southern Italy

${ }^{\mathrm{f}}$ Assumed to be the same as northeastern Romania

7.8 y starting from year 1993. Figure 1 shows the time-dependence of dietary intake of ${ }^{137} \mathrm{Cs}$ activity used in dose reconstruction (solid line) and that observed in Austria ${ }^{(27,28)}$, Belarus ${ }^{(23)}$, the Czech Republic $^{(34)}$, Finland ${ }^{(36)}$ and Norway ${ }^{(46)}$. As can be seen from Figure 1, the accepted time-dependence of dietary intake of ${ }^{137} \mathrm{Cs}$ agrees with that observed in those countries.

\section{External doses from radionuclides deposited on the ground}

The effective doses due to external irradiation from radionuclides deposited on the ground surface were calculated as:

$$
\begin{aligned}
D^{\mathrm{ext}}= & {\left[F_{\mathrm{u}} \cdot \mathrm{BF}_{\mathrm{u}}+\left(1-F_{\mathrm{u}}\right) \cdot \mathrm{BF}_{\mathrm{r}}\right] . } \\
& \sum_{i} \int_{t_{1}}^{t_{2}} H_{i}(t) \mathrm{d} t,
\end{aligned}
$$

where $D^{\text {ext }}$ is the effective dose from external irradiation from radionuclides deposited on the ground $(\mathrm{mSv}) ; F_{\mathrm{u}}$ is the fraction of urban population in the country ${ }^{(54)}$, unitless; $\mathrm{BF}_{\mathrm{u}}$ and $\mathrm{BF}_{\mathrm{r}}$ are behavioural factors that take into account the fraction of time spent indoors and the shielding provided by building materials, for the urban and the rural populations, respectively, unitless; $H_{i}(t)$ is the external effective 


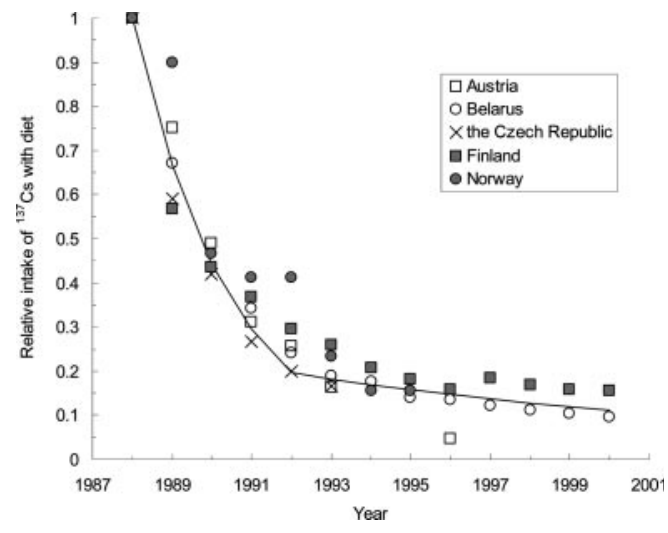

Figure 1. Time-dependence of dietary intake of ${ }^{137} \mathrm{Cs}$ activity: accepted in calculation (solid line) and observed in Austria ${ }^{(27,28)}$ (open squares), Belarus ${ }^{(23)}$ (open circles), the Czech Republic ${ }^{(34)}$ (crosses), Finland ${ }^{(36)}$ (closed squares) and Norway ${ }^{(46)}$ (closed circles).

dose rate due to radionuclide $i$ deposited on the ground surface $\left(\mathrm{mSv} \mathrm{d}^{-1}\right) ; t_{1}, t_{2}$ are times corresponding to the beginning and the end of the years that are considered $(d)$.

The external effective dose rate due to radionuclide $i$ deposited on the ground surface was calculated as follows:

$$
H_{i}(t)=\sigma_{i}(t) \cdot r(t) \cdot \mathrm{CF}_{i}^{\mathrm{ext}},
$$

where $\sigma_{i}(t)$ is the deposition density of radionuclide $i$ at time $t$ after the accident $\left(\mathrm{kBq} \mathrm{m}^{-2}\right) ; r(t)$ is an attenuation function that reflects the decreasing dose rate with time due to the migration of the deposited activity to deeper layers of soil, unitless; $\mathrm{CF}_{i}^{\text {ext }}$ is the conversion factor for radionuclide $i$ from the activity deposited per unit area of ground (as a plane source on the ground surface) to the effective dose rate for an adult $\left(\mathrm{mSv} \mathrm{d}^{-1}\right.$ per $\mathrm{kBq} \mathrm{m}^{-2}$ ).

The ground deposition of radionuclide $i$ was derived from the ground deposition of ${ }^{137} \mathrm{Cs}$ as follows:

$$
\sigma_{i}(t)=\sigma_{137_{\mathrm{Cs}}}(t) \cdot R_{i}(t),
$$

where $\sigma_{137_{\mathrm{Cs}}}(t)$ is the ground deposition of ${ }^{137} \mathrm{Cs}$ $\left(\mathrm{kBq} \mathrm{m} \mathrm{m}^{-2}\right) ; R_{i}(t)$ is the ratio of the activities of radionuclide $i$ and of ${ }^{137} \mathrm{Cs}$ in ground deposition at time $t$, unitless.

The estimation of the variation with time of the deposition density of ${ }^{95} \mathrm{Nb},{ }^{132} \mathrm{I}$ and ${ }^{140} \mathrm{La}$ takes into account the deposition of their precursors ${ }^{95} \mathrm{Zr},{ }^{132} \mathrm{Te}$ and ${ }^{140} \mathrm{Ba}$, respectively:

$$
\begin{aligned}
\sigma_{i}(t)= & \sigma_{i} \cdot \mathrm{e}^{-\lambda_{\mathrm{r}}^{i} \cdot t}+\sigma_{p, i} \cdot f_{i} \cdot \frac{\lambda_{\mathrm{r}}^{i}}{\lambda_{\mathrm{r}}^{i}-\lambda_{\mathrm{r}}^{p, i}} \cdot \\
& \left(\mathrm{e}^{-\lambda_{\mathrm{r}}^{p, i} \cdot t}-\mathrm{e}^{-\lambda_{\mathrm{r}}^{i} \cdot t}\right),
\end{aligned}
$$

where $\sigma_{i}$ and $\sigma_{p, i}$ are the initial deposition densities of radionuclide $i$ and of its parent, respectively $(\mathrm{kBq}$ $\left.\mathrm{m}^{-2}\right) ; \lambda_{\mathrm{r}}^{i}$ and $\lambda_{\mathrm{r}}^{p, i}$ are the radioactive decay constants of radionuclide $i$ and of its parent, respectively $\left(\mathrm{d}^{-1}\right)$.

The attenuation function, $r(t)$, that reflects the decreasing dose rate with time due to the migration of the deposited activity to deeper layers of soil was taken to be ${ }^{(18)}$ :

$$
r(t)=p_{1} \cdot \mathrm{e}^{-\lambda_{1} \cdot t}+p_{2} \cdot \mathrm{e}^{-\lambda_{2} \cdot t},
$$

where $p_{1}=0.49, p_{2}=0.51, \lambda_{1}=7.91 \times 10^{-4} \mathrm{~d}^{-1}$ and $\lambda_{2}=5.1 \times 10^{-5} \mathrm{~d}^{-1}$.

The values of the conversion factors from plane source on ground surface to effective dose to adults were taken from Ref. (8). To account for the effect of the soil-roughness and the initial penetration of radionuclides into the soil, a reduction factor of 0.82 was used ${ }^{(11)}$.

The behavioural factors, $\mathrm{BF}_{\mathrm{r}}$ and $\mathrm{BF}_{\mathrm{u}}$, were taken to be 0.36 and 0.18 for the rural and the urban populations, respectively, for the estimation of the doses delivered in 1986; for the estimation of the doses delivered in the following years, the values of $\mathrm{BF}_{\mathrm{r}}$ and $\mathrm{BF}_{\mathrm{u}}$, were taken to be 0.31 and 0.16 , respectively ${ }^{(1,5,17)}$.

\section{RESULTS AND DISCUSSION}

Country-wide average doses were estimated for each of 40 countries in Europe. In addition, doses were estimated for each of the most contaminated regions of Belarus, Russia and Ukraine. Age-dependent thyroid doses from the intake of ${ }^{131}$ I via inhalation and ingestion during the first 2 months after the accident (when practically all of the dose from the intake of ${ }^{131}$ I was received) were estimated. Average effective doses due to external irradiation from radionuclides deposited on the ground surface and from the intake of long-lived radionuclides, notably ${ }^{134} \mathrm{Cs}$ and ${ }^{137} \mathrm{Cs}$, were also estimated for the periods 1986, 1986-2005 and 1986-2065.

The geographical pattern of doses to the thyroid resulting from the intake of ${ }^{131} \mathrm{I}$ is shown in Figure 2 for children aged $1 \mathrm{y}$ at the time of the accident. The highest average thyroid doses were received in the Gomel region of Belarus ( 750 and $150 \mathrm{mGy}$ ) for young children and for adults, respectively), in the Bryansk region of the Russian Federation (210 and $25 \mathrm{mGy}$, respectively) and in the Zhytomir region in Ukraine (170 and $40 \mathrm{mGy}$, respectively). Doses to infants were consistently higher than doses received by adults (see Table 3 ).

Thyroid dose resulted primary from the ingestion of ${ }^{131} \mathrm{I}$ with milk and leafy vegetables. Contribution of that exposure pathway varied on dietary habits of population of different ages and in general was responsible for up to $80-95 \%$ of the total dose. 


\section{EXPOSURE IN EUROPE FROM CHERNOBYL}

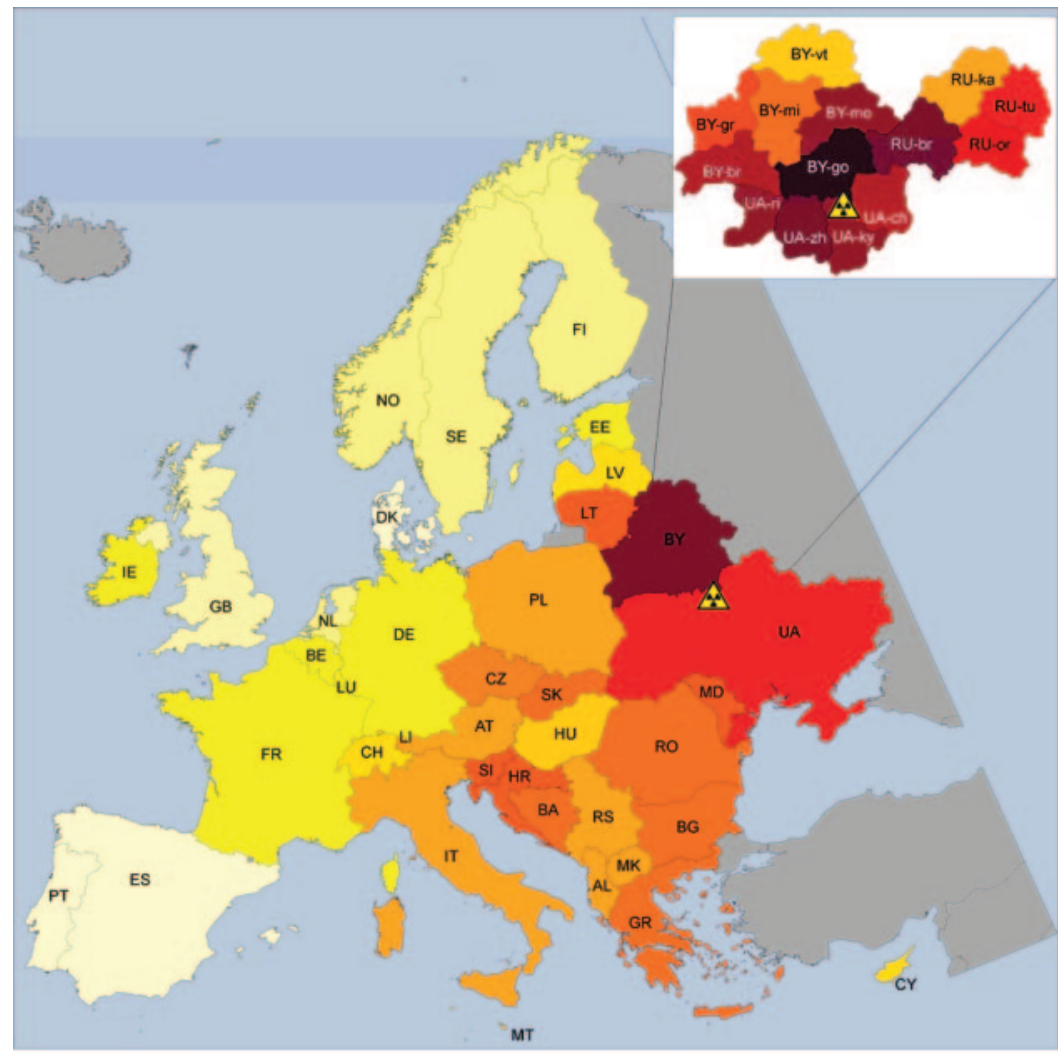

Thyroid dose in mGy:

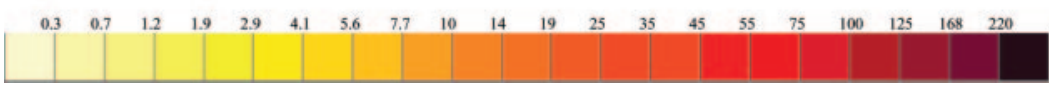

Figure 2. Spatial distribution of average country-specific thyroid doses from Chernobyl in Europe to children aged 1 y at the time of the accident. The radioactivity symbol denotes the location of the Chernobyl NPP. Names of countries are abbreviations according to ISO. For Belarus, Russian Federation and Ukraine the spatial distribution of doses is also given by Oblast. The following abbreviations were used for Oblasts. Belarus: for Brest, BY-br; for Gomel, BY-go; for Grodno, BY-gr; for Minsk, BY-mi; for Mogilev, BY-mo; for Vitebsk, BY-vt. Russia: for Bryansk, RU-br; for Kaluga, RU-ka; for Orel, RU-or; for Tula, RU-tu. Ukraine: for Chernihiv, UA-ch; for Kyiv, UA-ky; for Rivno, UA-ri; for Zhytomir, UA-zh.

In countries where countermeasures were applied shortly after the accident to reduce the intake of radionuclides with locally produced foodstuffs as well in the northern Europe the inhalation pathway contributed up to $50 \%$ of the total thyroid dose from the intake of ${ }^{131} \mathrm{I}$.

Average country-specific effective doses due to internal and external exposures from long-lived radionuclides are given in Table 3 for 1986 and for the 1986-2005 time periods. The spatial distribution of average country-specific effective doses accrued from 1986 to 2005 is shown in Figure 3. For the year 1986, effective doses were highest in Belarus and Ukraine, with average levels exceeding $0.5 \mathrm{mSv}$. Effective doses of the same order were also delivered in the most contaminated regions of Russia. In 1986-2005, the average effective doses were $2.8 \mathrm{mSv}$ in Belarus, $5.1 \mathrm{mSv}$ in the contaminated areas of Russia and $2.1 \mathrm{mSv}$ in Ukraine. In other countries, effective doses greater than, or about equal to, $1.0 \mathrm{mSv}$ were found for Finland, Austria, Moldova and Slovenia. Doses in the period 1986-2005 represent, on average, $\sim 85 \%$ of the lifetime dose from Chernobyl that would be accumulated by a person who lived until the year 2065.

For Europe as a whole, average effective dose in 1987 was half that of 1986. By 2005, the annual average dose was $<5 \%$ of that in 1986 . The average effective doses for the 1986-2005 time period in the Gomel region of Belarus and in the Bryansk region 
V. DROZDOVITCH ET AL.

Table 3. Country/region-specific dose estimates.

\begin{tabular}{|c|c|c|c|c|}
\hline \multirow[t]{2}{*}{ Country } & \multicolumn{2}{|c|}{$\begin{array}{l}\text { Thyroid dose } \\
\text { from the } \\
\text { intake of } \\
{ }^{131} \mathrm{I}(\mathrm{mGy}) \\
\text { for age group }\end{array}$} & \multicolumn{2}{|c|}{$\begin{array}{l}\text { Whole-body } \\
\text { effective dose } \\
(\mathrm{mSv}) \text { accrued } \\
\text { in the period }\end{array}$} \\
\hline & $1 \mathrm{y}$ & Adults & 1986 & 1986-2005 \\
\hline Albania & 9.4 & 2.8 & 0.16 & 0.52 \\
\hline Austria & 8.5 & 0.9 & 0.37 & 0.98 \\
\hline Belarus, Brest Oblast ${ }^{(22)}$ & 123 & 26 & 0.62 & 2.3 \\
\hline Belarus, Vitebsk Oblast ${ }^{(22)}$ & 7.0 & 2.0 & 0.05 & 0.12 \\
\hline Belarus, Gomel Oblast ${ }^{(22,70)}$ & 750 & 153 & 3.4 & 9.7 \\
\hline Belarus, Grodno Oblast ${ }^{(22)}$ & 28 & 5.8 & 0.32 & 0.85 \\
\hline Belarus, Minsk Oblast ${ }^{(22)}$ & 16.3 & 4.7 & 0.26 & 0.68 \\
\hline Belarus, Minsk-City ${ }^{(22)}$ & 100 & 18 & 0.17 & 0.68 \\
\hline Belarus, Mogilev Oblast ${ }^{(22)}$ & 128 & 31 & 1.5 & 4.4 \\
\hline Belgium & 2.1 & 0.4 & 0.01 & 0.03 \\
\hline Bosnia and Herzegovina & 18.4 & 5.7 & 0.12 & 0.41 \\
\hline Bulgaria ${ }^{(30)}$ & 16.6 & 3.1 & 0.25 & 0.64 \\
\hline Croatia & 21.4 & 5.0 & 0.19 & 0.47 \\
\hline Cyprus & 4.6 & 1.1 & 0.03 & 0.08 \\
\hline Czech Republic ${ }^{(34)}$ & 11.7 & 1.7 & 0.09 & 0.37 \\
\hline Denmark & 0.1 & 0.02 & 0.01 & 0.03 \\
\hline Estonia & 2.4 & 0.7 & 0.05 & 0.14 \\
\hline Finland $(36,71)$ & 1.1 & 0.3 & 0.21 & 1.36 \\
\hline France & 2.1 & 0.3 & 0.03 & 0.07 \\
\hline Germany & 2.2 & 0.3 & 0.06 & 0.17 \\
\hline Greece & 17.8 & 2.0 & 0.33 & 0.72 \\
\hline Hungary & 5.7 & 0.7 & 0.11 & 0.3 \\
\hline Iceland $^{\mathrm{a}}$ & - & - & 0.001 & 0.01 \\
\hline Ireland & 2.3 & 0.4 & 0.07 & 0.21 \\
\hline Italy & 8.2 & 1.2 & 0.15 & 0.33 \\
\hline Latvia & 5.1 & 1.5 & 0.04 & 0.10 \\
\hline Liechtenstein & 8.9 & 0.9 & 0.28 & 0.91 \\
\hline Lithuania $^{(44,59)}$ & 22.7 & 4.3 & 0.16 & 0.33 \\
\hline Luxembourg & 2.5 & 0.4 & 0.04 & 0.11 \\
\hline Macedonia & 9.4 & 2.8 & 0.14 & 0.47 \\
\hline Malta & 7.6 & 0.7 & 0.13 & 0.29 \\
\hline Moldova & 20.3 & 3.9 & 0.36 & 0.97 \\
\hline Netherlands & 0.9 & 0.3 & 0.02 & 0.05 \\
\hline Norway & 0.9 & 0.2 & 0.16 & 0.38 \\
\hline Poland & 7.8 & 0.8 & 0.11 & 0.25 \\
\hline Portugal & 0.008 & 0.002 & 0.001 & 0.003 \\
\hline Romania & 17.2 & 2.0 & 0.23 & 0.61 \\
\hline $\begin{array}{l}\text { Russia, Bryansk } \\
\text { Oblast }^{(20,72,73)}\end{array}$ & 210 & 26 & 3.2 & 10.9 \\
\hline Russia, Kaluga Oblast ${ }^{(16,20,73)}$ & 10 & 2 & 0.63 & 1.7 \\
\hline Russia, Orel Oblast ${ }^{(16,20,73)}$ & 60 & 10 & 1.2 & 2.8 \\
\hline Russia, Tula Oblast ${ }^{(16,20,73)}$ & 55 & 7 & 1.4 & 3.4 \\
\hline Serbia and Montenegro & 9.3 & 2.8 & 0.16 & 0.55 \\
\hline Slovakia & 17.3 & 2.1 & 0.16 & 0.41 \\
\hline Slovenia & 20.4 & 6.3 & 0.30 & 0.98 \\
\hline Spain & 0.1 & 0.02 & 0.004 & 0.009 \\
\hline Sweden & 0.9 & 0.2 & 0.12 & 0.31 \\
\hline Switzerland ${ }^{(51)}$ & 3.5 & 2.0 & 0.17 & 0.46 \\
\hline $\begin{array}{l}\text { Ukraine, Chernihiv } \\
\text { Oblast }^{(14,70)}\end{array}$ & 120 & 24 & 0.5 & 1.7 \\
\hline Ukraine, Kyiv Oblast ${ }^{(14,70)}$ & 166 & 33 & 1.4 & 3.9 \\
\hline Ukraine, Kyiv-City ${ }^{(14,70)}$ & 72 & 12 & 0.45 & 1.3 \\
\hline Ukraine, Rivno Oblast ${ }^{(14)}$ & 146 & 29 & 1.0 & 5.6 \\
\hline $\begin{array}{l}\text { Ukraine, Zhytomir } \\
\text { Oblast }^{(14,70)}\end{array}$ & 170 & 38 & 1.6 & 5.7 \\
\hline Ukraine, remainder ${ }^{(14)}$ & 28 & 5.4 & 0.57 & 1.9 \\
\hline United Kingdom & 0.7 & 0.08 & 0.02 & 0.05 \\
\hline
\end{tabular}

${ }^{a}$ External dose only from deposition of ${ }^{134,137}$ Cs was estimated of Russia were estimated to be $\sim 20$ times higher $(\sim 10 \mathrm{mSv})$ than those for Europe as a whole $(0.5 \mathrm{mSv})$.

Contributions of caesium ingestion and external exposure to the average effective dose accrued in the period 1986-2005 (with very small contribution of inhalation of caesium) varied between countries depending on the radionuclides mixture in deposition, the transfer of radionuclides to foodstuffs, dietary habits of population, implementation of countermeasures, etc. For the entire Europe, almost half $(54 \%)$ of effective dose was formed by the intake of ${ }^{134,137}$ Cs with foodstuffs while external exposure accounts for $46 \%$.

\section{Comparison with UNSCEAR 1988 Report}

Doses estimated in this paper were compared with doses published in the UNSCEAR 1988 Report $^{(5)}$. The comparison was limited to the countries of Northern, Central and Western Europe. Former states of the USSR (Estonia, Latvia, Lithuania, Moldova), Albania and Liechtenstein were not included in the comparison as doses for these countries were not estimated in the UNSCEAR 1988 Report $^{(5)}$. In addition, the comparison did not include the republics of the former Yugoslavia (Bosnia and Herzegovina, Croatia, Macedonia, Serbia and Montenegro, Slovenia), the Czech Republic, four contaminated Oblasts in Russia, Slovakia and Ukraine as the doses published in the UNSCEAR 1988 Report $^{(5)}$ were for specific sub-regions that did not cover the entire territory of these countries.

Figure 4 shows the ratios of thyroid doses from the intake of ${ }^{131} \mathrm{I}$ for infants estimated in this paper to those contained in the UNSCEAR 1988 Report $^{(5)}$. As can be seen from the figure, there is good agreement between the two estimates for the majority of countries. This is not surprising, as the same input data were used for dose reconstruction in these countries and only the dose coefficients ${ }^{(6,7)}$ used in current estimates reflect a difference between the two approaches. For other countries, Belarus, Bulgaria, Finland, Italy and Switzerland, the difference between the two sets of doses is more significant. In particular, thyroid doses estimated for Belarus differ significantly from the doses in the UNSCEAR 1988 Report $^{(5)}$. Current estimates are lower compared with previous estimates ${ }^{(5)}$ by a factor of 2 for Switzerland, Finland, and Bulgaria. Thyroid doses for these countries were estimated taking into account countermeasures (Switzerland) or based on direct thyroid measurements (Bulgaria). On the other hand, current estimates of thyroid dose for Italy are $\sim 2$ times higher than previous estimates ${ }^{(5)}$. The thyroid dose calculated in this paper for Italy is nearly median between those doses estimated taking 


\section{EXPOSURE IN EUROPE FROM CHERNOBYL}

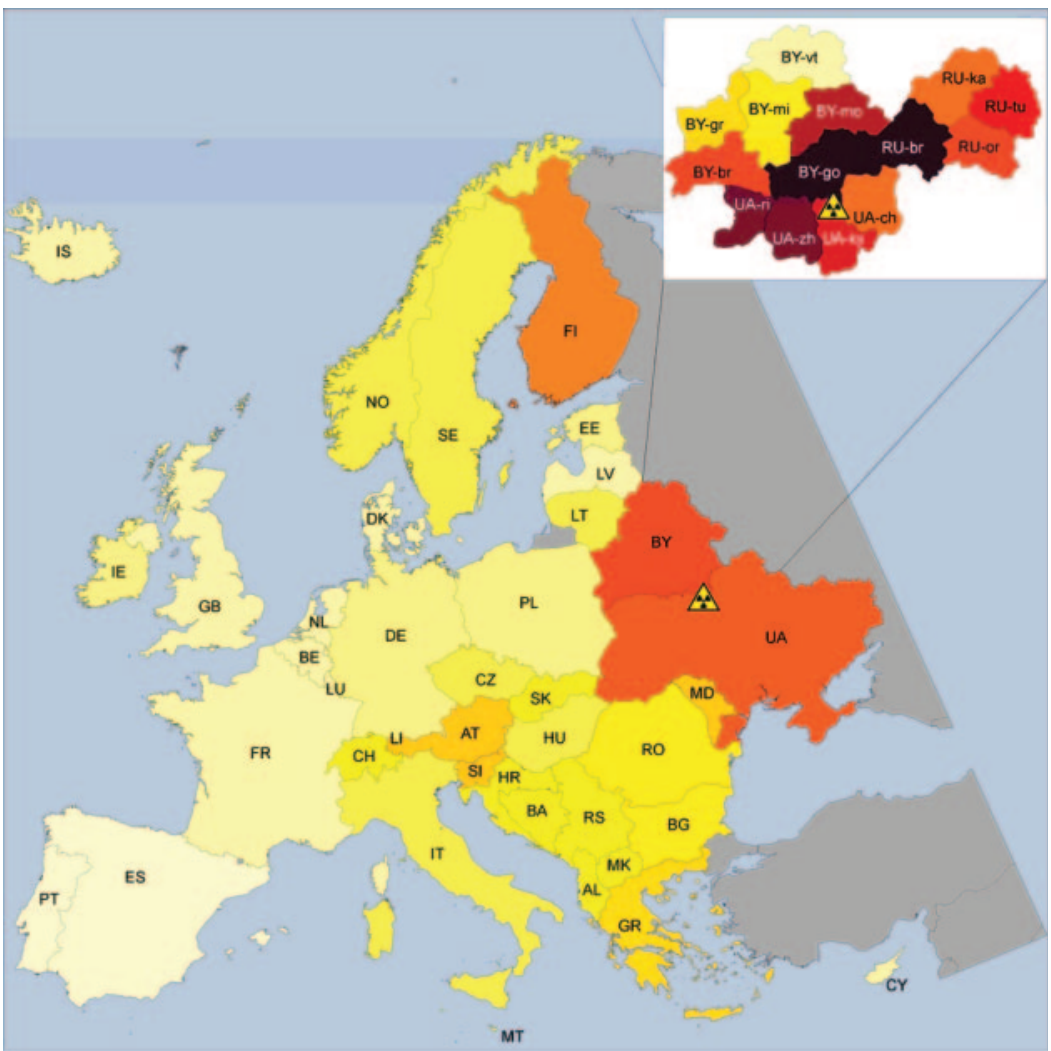

Effective dose in mSv:

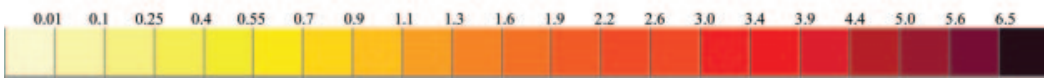

Figure 3. Spatial distribution of average country-specific effective doses from Chernobyl in Europe accrued in the period 1986-2005. Abbreviations are the same as in Figure 2.

countermeasures into account, and those estimates without adjusting for countermeasures ${ }^{(4)}$, while the doses evaluated in the UNSCEAR 1988 Report $^{(5)}$ are doses estimated taking countermeasures into account.

Figure 5 shows ratios of whole-body doses for adults: those estimated in this paper to those published in the UNSCEAR 1988 Report $^{(5)}$. The difference between the two sets of country-specific effective doses could be the result of the following factors:

(1) The difference in country-specific ${ }^{137} \mathrm{Cs}$ ground deposition densities used for dose reconstruction. As mentioned above, the deposition densities of ${ }^{137} \mathrm{Cs}$ from Chernobyl fallout contained in the Atlas ${ }^{(2)}$ were used in this paper. It might be expected, that deposition data from a comprehensive monitoring programme ${ }^{(2)}$ would be different from those published in 1988, which was information obtained in a rather short period after the accident. Indeed, population-weighted deposition densities of ${ }^{137} \mathrm{Cs}$ derived from the Atlas ${ }^{(2)}$ and given in the UNSCEAR 1988 Report $^{(5)}$ are, respectively, 0.3 and $0.8 \mathrm{kBq} \mathrm{m}^{-2}$ in Belgium, 0.3 and $1.8 \mathrm{kBq} \mathrm{m}^{-2}$ in The Netherlands, 2.8 and $4.7 \mathrm{kBq} \mathrm{m}^{-2}$ in Germany, 6.5 and $9.7 \mathrm{kBq} \mathrm{m}^{-2}$ in Romania, 0.36 and $1.3 \mathrm{kBq} \mathrm{m}^{-2}$ in Denmark, 1.3 and $5.2 \mathrm{kBq} \mathrm{m}^{-2}$ in Poland, 1.2 and $2.7 \mathrm{kBq} \mathrm{m}^{-2}$ in Luxembourg, etc. The latest estimates of ${ }^{137} \mathrm{Cs}$ ground deposition densities in a majority of the European countries considered are lower than those reported in the UNSCEAR 1988 Report $^{(5)}$. On the other hand, deposition densities of ${ }^{137} \mathrm{Cs}$ are, respectively, $0.06^{(2)}$ and $0.03^{(5)} \mathrm{kBq} \mathrm{m}^{-2}$ in Spain. As ${ }^{137} \mathrm{Cs}$ ground deposition density is one of the main input parameter for the estimation of external dose, difference in deposition used for dose calculation led to difference in dose estimates. 


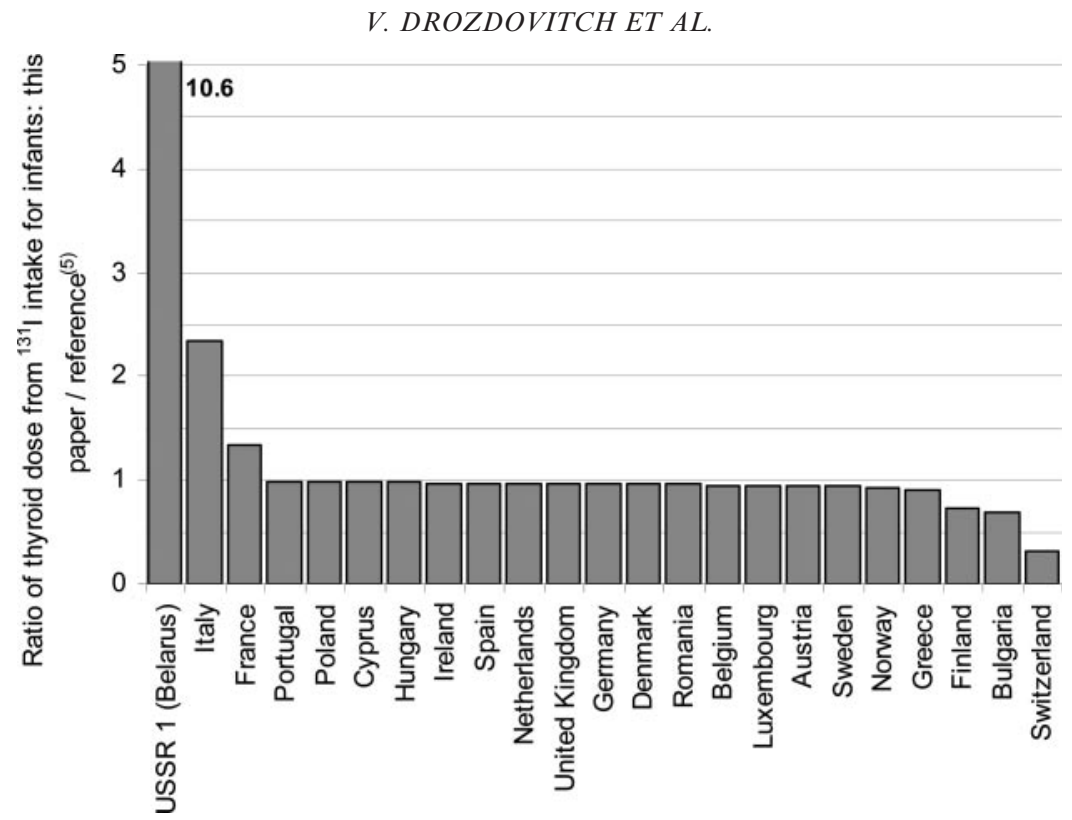

Figure 4. Ratios of thyroid doses from the intake of ${ }^{131} \mathrm{I}$ for infants: estimated in this paper to given in UNSCEAR 1988 Report $^{(5)}$.

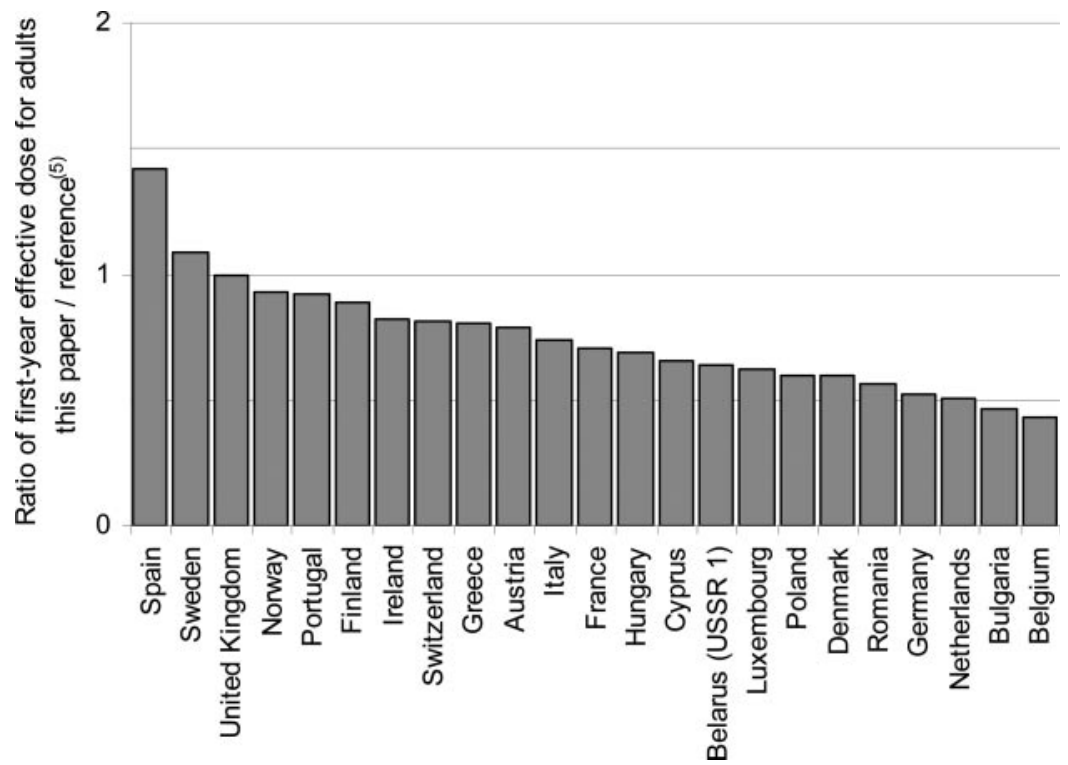

Figure 5. Ratios of effective dose for adults: estimated in this paper to given in UNSCEAR 1988 Report $^{(5)}$.

(2) This paper considers exposure due to inhalation of ${ }^{134} \mathrm{Cs}$ and ${ }^{137} \mathrm{Cs}$ only, while inhalation dose from the intake of a mixture of radionuclides was provided in the UNSCEAR 1988 Report $^{(5)}$. However, inhalation dose is rather small compared with dose from caesium ingestion and external exposure.

\section{Uncertainties in dose estimates}

Within a specific settlement or age group, the individual doses show a significant variability. Uncertainty factors of average doses over the settlement might vary in the range 1.6-2.4 for thyroid doses 


\section{EXPOSURE IN EUROPE FROM CHERNOBYL}

from the intake of ${ }^{131} \mathrm{I}^{(74,75)}$ and $1.2-1.5$ for external doses from radionuclides deposited on the ground $^{(18,76,77)}$. Sources of uncertainties are fluctuations in the radionuclides concentration in foodstuffs produced at the same location, as well as difference in behaviours and dietary habits from one individual to another, and inter-person variability in the metabolic parameter values. These uncertainties are important when individuals are considered.

However, they are smoothed out to great extent when average dose over the population of a large region is estimated, and the uncertainty of average doses over the population of a country is much lower. This uncertainty associated with the spatial variation of the radionuclides concentration in air, soil and in foodstuffs. The regional average concentration may differ significantly from the result obtained in a few measurement points in the region. Variability in dietary habits between regions of country is also source of uncertainty. In this paper uncertainties in doses were subjectively estimated based on the availability and reliability of radiation data used for dose reconstruction for each particular country. While errors in mean population doses were assumed to be smallest in the most contaminated countries (Belarus, Ukraine and the Russian Federation) where comprehensive dose reconstruction has been done on the basis of results of intensive radiation monitoring, higher uncertainties were assigned to dose estimates obtained from very limited data (Albania, Bosnia and Herzegovina, Iceland, Macedonia).

Assuming that the estimated doses are lognormally distributed, the geometric standard deviation of the distribution of the average thyroid dose estimates was evaluated to range from 1.2 in the most contaminated areas, where they were based on direct thyroid measurements (Gomel region in Belarus, Bryansk region in Russia, and Kiev and Zhytomir regions in Ukraine) to 2.0 in the least contaminated countries. The geometric standard deviation of the average effective dose estimates ranged from 1.1 in the most contaminated areas (Belarus, the most contaminated regions of Russia, and Ukraine) to 1.6 in the least contaminated countries.

Although this study focuses on the evaluation of average for country doses, it is obvious that there was variation in exposure levels between different regions of countries as well as between individuals. This variation of doses is not caused only by the difference in ${ }^{137} \mathrm{Cs}$ deposition but also by different nutritional habits and by the countermeasures. A number of countries took measures to reduce the population exposure to fallout from the Chernobyl accident. The most effective of these measures were the prohibition on feeding lactating cows with fresh grass and the recommendation to avoid consuming fresh milk and leafy vegetables. These measures, when taken during the few first weeks after the accident, resulted in a substantial reduction of the doses, especially in the thyroid doses to children $^{(27,51)}$. Later, countermeasures were also effective in reducing internal exposure from radiocaesium ingestion $^{(12,46,78,79)}$.

\section{CONCLUSIONS}

On the occasion of the 20th anniversary of the Chernobyl accident an attempt has been made to evaluate the impact of the Chernobyl accident on the global burden of human cancer in Europe. For this, country-wide average doses were estimated for 40 countries in Europe; in addition, doses were estimated for each of the most contaminated regions of Belarus, Russia and Ukraine. Age-dependent thyroid doses from the intake of ${ }^{131}$ I via inhalation and ingestion during the first 2 months after the accident (when practically all of the dose from the intake of ${ }^{131}$ I was received) were estimated. Average effective doses due to external irradiation from radionuclides deposited on the ground surface and from the intake of long-lived radionuclides, notably ${ }^{134} \mathrm{Cs}$ and ${ }^{137} \mathrm{Cs}$, were also reconstructed for the periods 1986, 1986-2005 and 1986-2065.

Dose estimates are based on the analysis and compilation of data either provided by experts from Belarus, Bulgaria, Croatia, the Czech Republic, Finland, Lithuania, the Russian Federation, Switzerland and Ukraine or published in the scientific literature for those and other countries in Europe. The average individual doses to the thyroid from the intake of ${ }^{131} \mathrm{I}$ for children aged $1 \mathrm{y}$ were found to vary from $0.008 \mathrm{mGy}$ in Portugal up to $750 \mathrm{mGy}$ in Gomel Oblast (Belarus). The average individual effective doses from external exposure and ingestion of long-lived radiocaesium accrued in the period 1986-2005 varied from almost zero in Portugal to $\sim 10 \mathrm{mSv}$ in Gomel Oblast (Belarus) and Bryansk Oblast (Russia). The average individual effective dose from the Chernobyl fallout for the 1986-2005 time periods for Europe as a whole was estimated to be $\sim 0.5 \mathrm{mSv}$. In comparison, the average effective dose from natural background radiation, excluding radon, over the same $20 \mathrm{y}$ was of the order of $20 \mathrm{mSv}$.

This study focuses on the evaluation of average for country doses. Therefore, doses are associated with uncertainties arising from the following main sources: heterogeneity and spatial variation observed within regions in the radionuclides concentration in air, soil and in foodstuffs; and uncertainties in sampling which may lead to the fact that the regional average concentration may differ from the result obtained in a few measurement points in the region (especially, in less contaminated countries). It should 


\section{DROZDOVITCH ET AL.}

be noted that more radiation data that were not taken into account in this paper might be available for some countries and might improve the results and lower uncertainties in exposure assessment to the population of Europe.

\section{ACKNOWLEDGEMENTS}

The authors convey special thanks to Prof. I. Likhtarev and Dr L. Kovgan (Radiation Protection Institute, Kiev, Ukraine), Prof. M. Balonov, Drs G. Bruk and I. Zvonova (Institute of Radiation Hygiene, St Petersburg, Russia) who provided data used in this paper and for their valuable comments on draft. The authors acknowledge Drs. J Uyttenhove (Ghent University, Belgium), E. Realo (Institute of Physics, Tartu, Estonia), G. Dubois (Institute for Environment and Sustainability, Ispra, Italy), M. Morrey (HPA-RPD, UK) and E. Lazo (OECD/NEA, France) for the providing of information used in the study. The authors also thank $\operatorname{Dr}$ M. Boniol (IARC, France) for assistance in the production of the maps. The work for this publication was partially funded by the Ministry of Health of Switzerland.

\section{REFERENCES}

1. United Nations Scientific Committee on the Effects of Atomic Radiation. Sources and effects of ionizing radiation. UNSCEAR 2000 Report, Vol. 2 (NY: UNSCEAR, UN) pp. 451-566 (2000), ISBN 92142239-6.

2. European Commission. Atlas on ${ }^{137} \mathrm{Cs}$ deposition on Europe after the Chernobyl accident. (Brussels, Luxembourg: EC) (1998).

3. Cardis, E. et al. Estimates of the cancer burden in Europe from radioactive fallout from the Chernobyl accident. Int. J. Cancer 119, 1224-1235 (2006).

4. Nuclear Energy Agency. The radiological impact of the Chernobyl accident in OECD countries. (Paris: NEA, OECD) (1987), ISBN 92-64-13043-8.

5. United Nations Scientific Committee on the Effects of Atomic Radiation. Sources and effects of ionizing radiation. UNSCEAR 1988 Report (NY: UNSCEAR, UN) (1988).

6. International Commission on Radiological Protection. Age-dependent doses to members of the public from intake of radionuclides: Part 4. Inhalation dose coefficients. ICRP Publication 71. Ann. ICRP 25(3/4) (Oxford: Pergamon Press) (1995).

7. International Commission on Radiological Protection. Age-dependent doses to members of the public from intakes of radionuclides: Part 2. Ingestion dose coefficients. ICRP Publication 67. Ann. ICRP 23(3/4) (Oxford: Pergamon Press) (1993).

8. Eckerman, K. F. and Ryman, J. C. External exposures to radionuclides in air, water, and soil. Federal Guidance Report No. 12, EPA US, Washington, DC (1993).
9. Likhtarov, I., Kovgan, L., Vavilov, S., Chepurny, M., Bouville, A., Luckyanov, N., Jacob, P., Voillequé, P. and Voigt, G. Post-Chernobyl thyroid cancers in Ukraine. Report 1: Estimation of thyroid doses. Radiat. Res. 163, 125-136 (2005).

10. Likhtarev, I., Kovgan, L., Novak, D., Vavilov, S., Jacob, P. and Paretzke, H. G. Effective dose due to external irradiation from the Chernobyl accident for different population groups of Ukraine. Health Phys. 70, 87-98 (1996).

11. Likhtarev, I. A., Kovgan, L. N., Jacob, P. and Anspaugh, L. R. Chernobyl accident: retrospective and prospective estimates of external dose of the population of Ukraine. Health Phys. 82, 290-303 (2002).

12. Likhtarev, I. A., Kovgan, L. N., Vavilov, S. E., Gluvchinsky, R. R., Perevoznikov, O. N., Litvinets, L. N., Anspaugh, L. R., Kercher, J. R. and Bouville, A. Internal exposure from the ingestion of foods contaminated by ${ }^{137}$ Cs after the Chernobyl accident-Report. 1. Ingestion doses and countermeasures effectiveness for the adults of Rovno oblast of Ukraine. Health Phys. 70, 297-317 (1996).

13. Likhtarev, I. A., Kovgan, L. N., Vavilov, S. E., Perevoznikov, O. N., Litvinets, L. N., Anspaugh, L. R., Jacob, P. and Pröhl, G. Internal exposure from the ingestion of foods contaminated by ${ }^{137}$ Cs after the Chernobyl accident-Report. 2. Ingestion doses of the rural population of Ukraine up to 12 y after the accident (1986-1997). Health Phys. 79, 341-357 (2000).

14. All-Ukrainian Research Institute of Population and Territories Civil Defence from Technogenic and Natural Emergencies. Doses to population of Ukraine following the Chernobyl accident. In: 20 years after Chernobyl catastrophe: Future outlook, National Report of Ukraine, Kyiv, Atika (2006).

15. Zvonova, I. A., Balonov, M. I. and Bratilova, A. A. Thyroid dose reconstruction for population of Russia suffered after the Chernobyl accident. Radiat. Prot. Dosim. 79, 175-178 (1998).

16. Balonov, M. A. and Zvonova, I. A., Eds. Average thyroid doses to population of different ages resided in 1986 in settlements in Bryansk, Kaluga, Orel, and Tula Oblasts contaminated by radionuclides following the Chernobyl accident. Radiat. Risk (Special issue) (2002).

17. Golikov, V., Balonov, M., Erkin, V. and Jacob, P. Model validation for external doses due to environmental contaminations by the Chernobyl accident. Health Phys. 77, 654-661 (1999).

18. Golikov, V. Yu., Balonov, M. I. and Jacob, P. External exposure of the population living in areas of Russia contaminated due to the Chernobyl accident. Radiat. Environ. Biophys. 41, 185-193 (2002).

19. Bruk, G. Ya., Shutov, V. N., Balonov, M. I., Basalayeva, L. N. and Kislov, M. V. Dynamics of ${ }^{137} \mathrm{Cs}$ content in agricultural food products produced in regions of Russia contaminated after the Chernobyl accident. Radiat. Prot. Dosim. 76, 169-178 (1998).

20. Bruk, G. Ya., Ed. Average effective doses cumulated in 1986-2001 in population of settlements in Bryansk, Kaluga, Lipetsk, Orel, Ryazan and Tula Oblasts of Russian Federation included in zones of radioactive contamination. Reference Book, Moscow (2002) [In Russian]. 


\section{EXPOSURE IN EUROPE FROM CHERNOBYL}

21. Gavrilin, Yu. I., Khrouch, V. T., Shinkarev, S. M., Krysenko, N. A., Skryabin, A. M., Bouville, A. and Anspaugh, L. R. Chernobyl accident: reconstruction of thyroid dose for inhabitants of the Republic of Belarus. Health Phys. 76, 105-119 (1999).

22. Minenko, V., Gavrilin, Yu., Shinkarev, S., Khrouch, V., Shemiakina, E., Drozdovitch, V., Voilleque, P. and Luckyanov, N. Chernobyl accident: assessment of the collective thyroid dose for the Belarusian population. In: Proceedings of the IRPA-10, Hiroshima, May (2000), ISSN 11-263-1-8.

23. Minenko, V., Ulanovsky, A., Drozdovitch, V., Shemiakina, E., Gavrilin, Yu., Khrouch, V., Shinkarev, S., Bouville, A., Anspaugh, L. and Voillequé, P. Individual thyroid dose estimation for a case-control study of Chernobyl-related thyroid cancer among children of Belarus-Part II: Contribution from long-lived radionuclides and external radiation. Health Phys. 90, 312-327 (2006).

24. Bossew, P., Ditto, M., Falkner, T., Henrich, E., Kienzl, K. and Rappelsberger, U. Contamination of Austrian soil with caesium-137. J. Environ. Radioact. 55, 187-194 (2001).

25. Dubois, G. and Bossew, P. Chernobyl ${ }^{137}$ Cs deposition in Austria: analysis of the spatial correlation of the deposition levels. J. Environ. Radioact. 65, 29-45 (2003).

26. Mück, K. Long term reduction of caesium concentration in milk after nuclear fallout. Sci. Total Environ. 162, 63-73 (1995).

27. Mück, K. Fallout and exposure of the population in Austria. Kerntechnik 61, 260-270 (1996).

28. Schwaiger, M., Mueck, K., Benesch, T., Feichtinger, J., Hrnecek, E. and Lovranich, E. Investigation of food contamination since the Chernobyl fallout in Austria. Appl. Radiat. Isot. 61, 357-360 (2004).

29. Uyttenhove, J., Pomme, S., Van Waeyenberge, B., Hardeman, F., Buysse, J. and Gulot, J. P. Survey of the ${ }^{137}$ Cs contamination in Belgium by in-situ gammaspectrometry, a decade after the Chernobyl accident. Health Phys. 73, 644-646 (1997).

30. Chobanova, N., Hadgijeva, T. and Vassilev, G. Thyroid gland exposure of Bulgarian persons from radioactive contamination of the country after the Chernobyl accident in 1986. Roentgenol. Radiol. XLIV, 203-218 (2005). [In Bulgarian with English abstract].

31. Institute for Medical Investigation of Croatia. Data on radioactive contamination of Croatia following the Chernobyl accident and doses to population. Report, Zagreb, Croatia (1986).

32. Lokobauer, N., Franić, Z., Bauman, A., Maračić, M., Cesar, D. and Senčar, J. Radiation contamination after the Chernobyl accident and the effective dose received by the population of Croatia. J. Environ Radioact. 41, 137-146 (1998).

33. Malátová, I., Bučina, I., Češpírová, I., Drábová, D. and Thomas, J. Committed effective dose equivalents from internal contamination of the Czechoslovak population after the Chernobyl accident. Radiat. Prot. Dosim. 28, 293-301 (1989).

34. Malátová, I. and Skrkal, J. Re-evaluation of internal exposure from the Chernobyl accident to the Czech population. In: Proceedings of the Second European IRPA Congress on Radiation Protection, Paris, France, 15-19 May, p. 176 (2006).
35. Realo, E., Jõgi, J., Koch, R. and Realo, K. Studies on radiocaesiums in Estonian soils. J. Environ Radioact. 29, 111-119 (1995).

36. Muikku, M., Arvela, H., Järvinen, H., Korpela, H., Kostiainen, E., Mäkeläinen, I., Vartiainen, E. and Vesterbacka, K. Annoslakku 2004-Suomalaisten Keskimääräinen Efektiivinen annos. STUK-A211 (Helsenki: STUK) (2005).

37. Renaud, P., Pourcelot, L., Métivier, J.-M. and Morello, M. Mapping of ${ }^{137}$ Cs deposition over eastern France 16 years after the Chernobyl accident. Sci. Total Environ. 309, 257-264 (2003).

38. Kritidis, P. and Florou, H. Radiological impact in Greece of the Chernobyl accident - a 10-y retrospective synopsis. Health Phys. 80, 440-446 (2001).

39. Petropoulos, N. P., Anagnostakis, M. J., Hinis, E. P. and Simopoulos, S. E. Geographical mapping and associated fractal analysis of long-lived Chernobyl fallout radionuclides in Greece. J. Environ. Radioact. 53, 59-66 (2001).

40. Fehér, I. Experience in Hungary on the radiological consequences of the Chernobyl accident. Environ. Int. 14, 113-135 (1988).

41. Lofti, M., Mancioppi, S., Piermattei, S., Tommasino, L. and Azimi-Garakani, D. Calculation of the individual effective dose equivalent in Italy following the Chernobyl accident. J. Environ. Radioact. 13, 141-156 (1991).

42. Salvadori, G., Ratti, S. P. and Belli, G. An analysis of time-dependence for Chernobyl fallout in Italy. Health Phys. 71, 60-76 (1997).

43. Nedveckaite, T. and Filistovic, V. Estimates of thyroid equivalent dose in Lithuania following the Chernobyl accident. Health Phys. 69, 265-268 (1995).

44. Nedveckaite, T., Filistovic, V., Mastauskas, A. and Thiessen, K. Thyroid dosimetry in the western trace of the Chernobyl accident plume. Radiat. Prot. Dosim. 108, 133-141 (2004).

45. Henriksen, T. Fallout and radiation doses in Norway after the Chernobyl accident. Environ. Int. 14, 157-163 (1988).

46. Tveten, U., Brynildsen, L. I., Amundsen, I. and Bergan, T. D. S. Economic consequences of the Chernobyl accident in Norway in the decade 1986-1995. J. Environ. Radioact. 41, 233-255 (1998).

47. Krstić, D., Nikezić, D., Stevanović, A. and Jelić, M. Vertical profile of ${ }^{137} \mathrm{Cs}$ in soil. Appl. Radiat. Isot. 61, 1487-1492 (2004).

48. Hanusik, V. and Wirdzek, S. Calculation of individual dose equivalents on the territory of eastern Slovakia after the Chernobyl accident. Radiat. Prot. Dosim. 35, 41-45 (1991).

49. Slavik, O., Fulajtar, E., Müller, H. and Pröhl, G. Model for food chain transfer and dose assessment in areas of the Slovak Republic. Radiat. Environ. Biophys. 40, 59-67 (2001).

50. Holmberg, M., Edvarson, K. and Finck, R. Radiation doses in Sweden resulting from the Chernobyl fallout: $a$ review. Int. J. Radiat. Biol. 54, 151-166 (1988).

51. Huber, O., Jeschki, W., Prêtre, S. and Völkle, H. Effects in Switzerland of the Chernobyl reactor accident. Kerntechnik 61, 271-277 (1996).

52. Smith, F. B. and Clark, M. J. The transport and deposition of airborne debris from the Chernobyl nuclear power plant accident with special emphasis on the 


\section{DROZDOVITCH ET AL.}

consequences to the United Kingdom. Scientific Paper No. 42, UK Meteorological Office (1989).

53. Bell, J. N. B. and Shaw, G. Ecological lessons from the Chernobyl accident. Environ. Int. 31, 771-777 (2005).

54. United Nations. UN Common database, population division (2005). Available at: http://globalis.gvu.unu.edu/.

55. State Committee for Hydrometeorology of Republic of Belarus. Deposition density of ${ }^{137} \mathrm{Cs}$ and ${ }^{90} \mathrm{Sr}$ in the settlements of the Republic of Belarus. (Minsk: State Committee for Hydrometeorology of Republic of Belarus) (2002).

56. Antonov, A., Veleva, B., Adjarova, L. and Kolarova, M. Time and area distribution of low-level activities of technogenic radionuclides in the surface air and fallout over the territory of Bulgaria. Rare Nuclear Processes. World Scientific Publishers, pp. 407-419 (1992).

57. Bučina, I., Dvořák, Z., Malátová, I., Vrbová, H. and Drábová, D. Radionuclides from the Chernobyl accident in soil over the Czechoslovak territory: their origin, deposition and distribution. In: Proceedings of XV Regional Congress of IRPA-Radioecology of Natural and Artificial Radionuclides, Visby, Sweden, September, pp. 170-175 (1989).

58. Arvela, H., Markkanen, M. and Lemmelä, H. Mobile survey of environmental gamma radiation and fall-out levels in Finland after the Chernobyl accident. Radiat. Prot. Dosim. 32, 177-183 (1990).

59. Nedveckaite, T. Personal communication, Unpublished data, Institute of Physics, Vilnius, Lithuania (2006).

60. Balonov, M. I., Bruk, G. Ya., Golikov, V. Yu., Shutov, V. N., Savkin, M. N., Pitkevitch, V. A., Stepanenko, V. F., Vakulovsky, S. M. and Perminova, G. S. Reconstruction of average cumulated in 1986-1995 effective doses for inhabitants of settlements of Russian Federation radioactive contaminated following the accident on the Chernobyl NPP in 1986. Methodical Instructions MU 2.6.1.579-96, State Committee on Sanitary and Epidemiological Inspection of Russian Federation, Moscow (1996). [In Russian].

61. Russian State Committee for Hydrometeorology. Deposition density of ${ }^{137} \mathrm{Cs}$ in Russian settlements. (Obninsk: RCH) (2000).

62. Drozdovitch, V. V., Minenko, V. F., Ulanovsky, A. V. and Kukhta, T. S. Internal exposure from ingestion of foodstuffs contaminated by radiocaesium. Part I: doses to rural population of Belarus. Medical and Biological Aspects of the Chernobyl Accident 2, 12-16 (1996) [In Russian].

63. International Atomic Energy Agency. Radioactive contamination after Chernobyl accident in Bulgaria (10 years after the accident). Phrases, investigations, prognoses. National Report (Vienna: IAEA) (1996).

64. Rantavaara, A. and Haukka, S. Radioactivity of milk, meat, cereals and other agricultural products in Finland after the Chernobyl accident in 1986. STUK A58 (Helsenki: STUK) (1987).

65. International Commission on Radiological Protection. Basic anatomical and physiological data for use in radiological protection: Reference values. ICRP Publication
89. Ann. ICRP 32(3/4) (Oxford: Pergamon Press) (2002).

66. Dubois, G. ${ }^{131} \mathrm{I},{ }^{134} \mathrm{Cs}$, and ${ }^{137} \mathrm{Cs}$ measurements in air. personal communication (REM data bank at CEC Joint Research Centre Ispra) (2005).

67. Studies on environmental radioactivity in Finland in 1986. Annual report. STUK-55 (Helsenki: STUK) (1987).

68. Rantavaara, A. Radioactivity of foodstuffs in Finland in 1987 and 1988. Supplement 4 to the Reports STUK-A74 and STUK-A89. STUK A78 (Helsenki: STUK) (1991).

69. Roed, L. and Cannell, R. J. Relationship between indoor and outdoor aerosol concentration following the Chernobyl accident. Radiat. Prot. Dosim. 21, 107-110 (1987).

70. Pukkala, E., Kesminiene, A., Polyakov, S., Ryzhov, A., Drozdovitch, V., Kovgan, L. N., Kyyronen, P., Malakhova, I., Gulak, L. and Cardis, E. Breast cancer in Belarus and Ukraine after the Chernobyl accident. Int. J. Cancer 119, 651-658 (2006).

71. But, A., Kurttio, P., Heinävaara, S. and Auvinen, A. No increase in thyroid cancer among children and adolescents in Finland. Eur. J. Cancer 42, 1167-1171 (2006).

72. Zvonova, I. A., Bratilova, A. A. and Pochtennaja, G. T. Risk of radiogenic thyroid cancer among population of the Bryansk region after the Chernobyl accident. Med. Radiol. Radiat. Safety 50, 41-52 (2005) [In Russian].

73. Bruk, G. Ya. and Zvonova, I. A. Unpublished data. Institute of Radiation Hygiene (St Petersburg, Russia), personal communication (2006).

74. Gavrilin, Yu. et al. Individual thyroid dose estimation for a case-control study of Chernobyl-related thyroid cancer among children of Belarus. Part I: ${ }^{131} I$, shortlived radioiodines $\left({ }^{132} I,{ }^{133} I,{ }^{135} I\right)$, and short-lived radiotelluriums $\left({ }^{131 m} \mathrm{Te}\right.$ and $\left.{ }^{132} \mathrm{Te}\right)$. Health Phys. 86, 565-585 (2004).

75. Jacob, P. et al. Thyroid cancer risk in areas of Ukraine and Belarus affected by the Chernobyl accident. Radiat. Res. 165, 1-8 (2006).

76. Drozdovitch, V. V., Shevchuk, V. E. and Mirkhaidarov, A. K. Uncertainty analyses of external doses used to assess radiological consequences of the NPPs accident. In: Preprint of Institute of Power Engineering Problems IPEP 70, Minsk (2002) [In Russian].

77. Thornberg, C., Vesanen, R., Wallström, E., Zvonova, I., Jesko, T., Albinsson, J., Börjesson, J. and Mattsson, S. Long-term external radiation exposure of inhabitants in the western Bryansk region of Russia as a consequence of the Chernobyl accident. Radiat. Environ. Biophys. 40, 287-294 (2001).

78. Drozdovitch, V. V., Minenko, V. F., Ulanovsky, A. V. and Kukhta, T. S. Internal exposure from ingestion of foodstuffs contaminated by radiocaesium. Part III: Effectiveness of countermeasures in restriction of doses to rural population. Medical and Biological Aspects of the Chernobyl Accident, 4, 65-72 (1996) [In Russian].

79. Fesenko, S., Jacob, P., Alexakhin, R., Sanzharova, N. I., Panov, A., Fesenko, G. and Cecille, L. Important factors governing exposure of the population and countermeasure application in rural settlements of the Russian Federation in the long term after the Chernobyl accident. J. Environ. Radioact. 56, 77-98 (2001). 